\title{
Prevalence and Perceived Causes of Nutritional Anemia Among Adolescent Girls
}

\author{
Sonal Dhobe and Seema Singh \\ Department of Medical Surgical Nursing (Cardiovascular and Thoracic Nursing), Smt. \\ Radhikabai Meghe Memorial College of Nursing, Datta Meghe Institute of Medical \\ Sciences Sawangi, Wardha, Maharashtra, India. \\ orresponding author email:dhobesonal67@gmail.com
}

\section{ABSTRACT}

Nutritional anemia is a disorder that cause due to a lack of one or more vital nutrients, such as iron, protein, vitamin B12, and other vitamins and minerals. The hemoglobin content in the blood is lower than usual. 1. To assess the prevalence of nutritional anemia among adolescent girls. 2. To assess perceived causes of nutritional anemia among adolescent girls. 3. To associate the demographic variable with prevalence and perceived causes of nutritional anemia among adolescent girls. A cross sectional study was conducted among adolescent girls were age of 10 to 15 years, the sample size can be calculated statistically by using the prevalence of previous studies and the sample size was 220 adolescent girls selected in a particular community area from Wardha district. Ethical approval was obtained from IEC, DMIMS (DMIMS (DU)/ IEC/Aug-2019/8685). The sample collection was done by using non-probability convenience sampling. The portable hemoglobinometer (Accusure HB meter) used for analyzing the $\mathrm{Hb}$ level and structure questionnaire scale was formulated on the based on the causes behind the nutritional anemia. Prevalence of nutritional anemia among adolescent girls was found 56.4\%.Within that 17.3\% of them had mild anemia, 35.5\% of them had moderate anemia and 3.6\% of them had severe anemia. The perceived causes of nutritional anemia was found, 4.03\% of adolescent girls have genetic history of any type of anemia, 9.68\% of them had a history of heavy menstrual flow, 10.48\% of them were suffering from chronic disease in past or more than 3 months in the recent year time, 91.94\% of them think that they are taken inadequate intake of iron in the food, $0.81 \%$ had a hookworm infection, 25\% of them replied that drink coffee or tea will decrease iron absorption, 89.52\% of them take diet low in fruits, vegetable and cereals, 38.71\% of the adolescent girls always eat overcooked food, 4.84\% of them take any type of medicine and 19.35\% of the adolescent girls eat junk food. Conclusion: This study finding shows that the demographic variables is shows significant association between the prevalence of nutritional anemia with educational status of caretakers. In association with the perceived causes of nutritional anemia shows significant association with type of diet.

\section{KEY WORDS: PREVALENCE, PERCEIVED CAUSES, NUTRITIONAL ANEMIA, ADOLESCENT GIRLS.}

\section{INTRODUCTION}

Nutritional anemia is a disorder that cause due to a lack of one or more vital nutrients, such as iron, proteins, vitamin B12 and other vitamins and minerals. The hemoglobin content in the blood is lower than usual.1 All pathological conditions in which the concentration of

Biosc Biotech Res Comm P-ISSN: 0974-6455 E-ISSN: 2321-4007

\section{rossef}

Identifiers and Pagination

Year: 2021 Vol: 14 No (9) Special Issue

Pages: 246-252

This is an open access article under Creative

Commons License Attribn 4.0 Intl (CC-BY).

DOI: $h t t p: / / d x$.doi.org/10.21786/bbrc/14.9.46 blood hemoglobin falls to an abnormally low level due to the deficiency of one or more nutrients are described by the word nutritional anemia. Iron, folic acid, and vitamin B12 are the principal elements needed in hemoglobin synthesis.2 Nutritional anemia in children has been shown to be associated with decreased emotional, physical and cognitive health and is a potential cause for maternal mortality rates. 3 Anemia is characterized by hemoglobin $(\mathrm{Hb})$ levels of $<12.0 \mathrm{~g} / \mathrm{dL}$ in women and $<13.0 \mathrm{~g} / \mathrm{dL}$ in men, according to the World Health Organization.4 Anemia is a major global health issue, particularly in developing countries.

This basic health problem is yet to be resolved, and it threatens to impact the health, quality of life, and working capability of billions of people worldwide. 5 Anemia

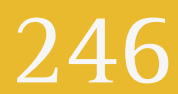


impacts 1.62 billion people worldwide. This gap has been filled by the WHO Global Database on Anemia, data from 93 different countries, In the case of preschoolage children, data from as many as 76 percent of the population was analyzed and used to create statistical models to produce national prevalence estimates for countries. The highest prevalence is 47.4 percent in preschool-aged girls, and the lowest prevalence is 12.7 percent in adults. Non-pregnant women, on the other hand are the demographic group with the largest number of people affected (Cappellini 2015).

6 As compared to other developing countries, the prevalence of anemia in all classes is higher in India. Anemia affects in India around 50\% of the population. As more women are affected by it than men, the issue becomes more severe. It is reported that about 20 percent to 40 percent of maternal deaths in India are due to anemia, and some form of anemia affects one in every two Indian women (56 percent). Anemia in females is characterized as less than $12 \mathrm{~g} / \mathrm{dL}$ hemoglobin. Mild anemia is characterized as a level of $10-11.9 \mathrm{~g} / \mathrm{dL}$ of hemoglobin, moderate anemia as a level of 7-9.9 g/dL of hemoglobin, and extreme anemia as a level of less than $7 \mathrm{~g} / \mathrm{dL}$ of hemoglobin among women. Studies by the Indian Council of Medical Research (ICMR) and the District Level Household Survey (DLHS) have shown that the prevalence of anemia in pre-school infants, pregnant and lactating mothers, and teenage girls is very high (ranging from 80->90\%).

In particular, low birth weight babies, young children and women of childbearing age are at risk for anemia. This is how anemia starts in infancy, worsens in girls during puberty, and gets worse during pregnancy. In India, teenage girls, who make up a significant segment of the population, are a vulnerable group at higher risk of morbidity and mortality. Due to increased demand for iron for hemoglobin, myoglobin and to make up for iron loss due to menstruation and poor dietary habits. Teenage girls are especially vulnerable to iron deficiency anaemia.7 The rapid physical, psychological and cognitive growth defines the adolescent phase. In the human lifespan, adolescent age is a vulnerable time for the development of anemia. Adolescents cover almost one tenth of the population in India and constitute a vital sector of the population in society (Benoist et al., 2005).

Present and future well-being of the adolescent can depend on their current nutritional status. The teenage age is the important years of growth, anemia has some long-term effects at this stage of life, such as growth retardation, poorer academic results, decreased immunity, irregular menstrual cycles, and later poor birth complications such as intrauterine growth restriction, birth defects, increased perinatal morbidity, and mortality. The most common nutritional condition globally is anemia. Because of the requirements for rapid growth and menstrual blood loss, anemia is normal in teenage girls. The WHO reports shows the prevalence of anemia among teenage girls in developing countries at 27 percent and in developed countries at 6 percent.

\section{Objectives of the Study}

1. To assess the prevalence of nutritional anemia among adolescent girls.

2. To assess the perceived causes of nutritional anemia among adolescent girls.

3. To associate the demographic variable with prevalence and perceived causes of nutritional anemia among adolescent girls.

\section{MATERIAL AND METHODS}

A cross sectional study was conducted among adolescent girls were age of 10 to 15 years, the sample size can be calculated statistically by using the prevalence of previous studies and the sample size was 220 adolescent girls selected in a particular community area from Wardha district. Ethical approval was obtained from IEC, DMIMS (DMIMS (DU)/IEC/Aug-2019/8685). The sample collection was done by using non-probability convenience sampling. The portable hemoglobinometer (Accusure $\mathrm{HB}$ meter) used for analyzing the $\mathrm{Hb}$ level and structure questionnaire scale was formulated on the based on the causes behind the nutritional anemia. The investigator inspect the selected community in the Wardha district and received the permission needed from the authorities concerned (Chaudhary \&t Dhage 2008).

In order to ensure better cooperation during the data collection, the investigator introduced herself and told them about the purpose of the research. The investigator approached the adolescent girls from age between 10-15 years in selected community and explained the purpose of the study and explain how it will be beneficial for them. The investigator took the consent from individual adolescent girls for the study. The investigator personally visited each adolescent girls, and provide orientation about the study and also administered structured questionnaire to them. Investigator instructed them not to interact with each other, doubts were clarified. A good rapport was maintained. On the first day, each participant was given a questionnaire. The questionnaire were collected soon after it was filled up. On the same day the $\mathrm{Hb}$ estimation was done by using portable Hemoglobinometer. After that those girls found anemic fill the structured questionnaire regarding perceived causes of nutritional anemia and collect all the forms. Given a health education Regarding Diet.

Statistical Analysis: The descriptive and inferential statistics was done by using SPSS 23 software. A master sheet will be prepared by the investigator to measure the data. Using frequency and percentage, baseline Performa containing sample characteristics was analyzed. Prevalence of nutritional anemia among adolescent girls, demographic variable, perceived causes of nutritional anemia can calculated by using mean, mean percentage and standard deviation. The 
significance of the variance between the prevalence of nutritional anemia and demographical variables were calculated using " $\mathrm{t}$ " test. The significance of the variance between the prevalence and perceived causes of nutritional anemia were calculated using " $t$ " test. The correlation between prevalence of nutritional anemia and demographical variables were determined by ANOVA and unpaired " $\mathrm{t}$ " test.

\section{RESULTS AND DISCUSSION}

Percentage wise distribution of adolescent girls according to their demographic characteristics. The above table no. 1 shows that total $15.50 \%$ of the adolescent girls were of 10 years, each $12.70 \%$ were of 11 years and 13 years, $15.90 \%$ were of 12 years, $19.50 \%$ of 14 years and $23.70 \%$ of adolescent girls were of 15 years of age. Among all adolescent girls $28.20 \%$ of the adolescent girls were educated upto 4-5th standard, 27.70\% upto 6-7th standard, $41.40 \%$ of them were educated upto 8-9th standard and $2.70 \%$ of the adolescent girls were educated upto 10th standard. Minority $0.50 \%$ of the caretakers of adolescent girls were illiterate, $10 \%$ of them were educated upto primary standard, $12.30 \%$ of them were educated upto secondary standard, $23.20 \%$ of them were educated upto SSC, $24.40 \%$ of them were educated upto HSC, $19.10 \%$ of them were upto under graduation and $10.50 \%$ of the adolescent girls were educated upto graduation and above.

Out of 220, 52.30\% of the adolescent girls were having monthly family income of 5001-10000 Rs, $37.20 \%$ were having between 10001-15000 Rs, 8.20\% were having monthly family income of 15001-20000 Rs and only $2.30 \%$ of the adolescent girls were having monthly family income of 20001 Rs and above. 50\% of the adolescent girls were from joint families, $46.40 \%$ of them were from nuclear families and 3.60\% of them were from extended families. 35\% of the adolescent girls were vegetarian, no one is non-vegetarian.

Assessment with prevalence of nutritional anemia: The above table no. 2 and figure no. 1 shows that $43.6 \%$ of adolescent girls had no anemia, $17.3 \%$ of them had mild anemia, 35.5\% of them had moderate anemia and $3.6 \%$ of them had severe anemia. Overall prevalence was $56.4 \%$.

Assessment with perceived causes of nutritional anemia among those adolescent girls are anemic: The above table no. 3 and figure no. 2 shows that $4.03 \%$ of adolescent girls have genetic history of any type of anemia, 9.68\% of them had a history of heavy menstrual flow, 10.48\% of them were suffering from chronic disease in past or more than 3 months in the recent year time, 91.94\% of them think that you have taken inadequate intake of iron in the food, $0.81 \%$ had a hookworm infection, 25\% of them replied that drink coffee or tea will decrease iron absorption, $89.52 \%$ of them take diet low in fruits, vegetable and cereals, $38.71 \%$ of the adolescent girls always eat overcooked food, $4.84 \%$ of them take any
Table 1. Percentage wise distribution of adolescent girls according to their demographic characteristics.

\begin{tabular}{|c|c|c|}
\hline $\begin{array}{l}\text { Demographic } \\
\text { Variables }\end{array}$ & $\begin{array}{c}\text { No. of } \\
\text { adolescent } \\
\text { girls }\end{array}$ & $\begin{array}{c}\text { Percentage } \\
(\%)\end{array}$ \\
\hline Age(yrs) & & \\
\hline 10 yrs & 34 & 15.5 \\
\hline $11 \mathrm{yrs}$ & 28 & 12.7 \\
\hline 12 yrs & 35 & 15.9 \\
\hline 13 yrs & 28 & 12.7 \\
\hline 14 yrs & 43 & 19.5 \\
\hline 15 yrs & 52 & 23.7 \\
\hline Education of adolescent girls & & \\
\hline 4-5thstd & 62 & 28.2 \\
\hline 6-7thstd & 61 & 27.7 \\
\hline 8-9thstd & 91 & 41.4 \\
\hline 10thstd & 6 & 2.7 \\
\hline Education of caretakers & & \\
\hline Illiterate & 1 & 0.5 \\
\hline Primary & 22 & 10.0 \\
\hline Secondary & 27 & 12.3 \\
\hline SSC & 51 & 23.2 \\
\hline HSC & 54 & 24.4 \\
\hline Undergraduate & 42 & 19.1 \\
\hline Graduate and above & 23 & 10.5 \\
\hline Monthly family income(Rs) & & \\
\hline 5001-10000 Rs & 115 & 52.3 \\
\hline $10001-15000 \mathrm{Rs}$ & 82 & 37.2 \\
\hline $15001-20000 \mathrm{Rs}$ & 18 & 8.2 \\
\hline 20001 Rs and above & 5 & 2.3 \\
\hline Type of family & & \\
\hline Joint & 110 & 50.0 \\
\hline Nuclear & 102 & 46.4 \\
\hline Extended & 8 & 3.6 \\
\hline Type of diet & & \\
\hline Vegetarian & 77 & 35.0 \\
\hline Non Vegetarian & 143 & 65.0 \\
\hline Mixed & 0 & 0.0 \\
\hline
\end{tabular}

type of medicine and $19.35 \%$ of the adolescent girls eat junk food. Association of prevalence of nutritional anemia among adolescent girls

This table no.4 shows the association of prevalence of nutritional anemia with demographic variable of adolescent girls. There is significant association with educational level of caretakers of adolescent girls. The tabulated ' $\mathrm{N}$ ' values was $28.87(\mathrm{df}=18)$ which is much less than the calculated ' $N 2$ ' i.e. 72.73 at $5 \%$ level of significance. Also the calculated ' $p$ ' $=0.0001$ which was much less than the acceptable level of significance i.e. ' $p$ ' $=0.05$. Hence it is interpreted that educational 
This table no.4 shows the association of prevalence of nutritional anemia with demographic variable of adolescent girls. There is significant association with educational level of caretakers of adolescent girls. The tabulated ' $N 2$ ' values was $28.87(\mathrm{df}=18)$ which is much less than the calculated ' $\$ 2$ ' i.e. 72.73 at $5 \%$ level of significance. Also the calculated ' $p$ '=0.0001 which was much less than the acceptable level of significance i.e. ' $p$ ' $=0.05$. Hence it is interpreted that educational level of caretakers of adolescent girls is statistically associated with prevalence of nutritional anemia.

Table 2. Assessment with prevalence of nutritional anemia

\begin{tabular}{l|c|c|c|}
\hline \multirow{2}{*}{$\begin{array}{l}\text { Prevalence of } \\
\text { nutritional anemia }\end{array}$} & \multirow{2}{*}{ Score Range } & \multicolumn{2}{|c|}{ Level of perception Score } \\
\cline { 3 - 4 } & & No of adolescent girls & Percentage \\
\hline No anemia & $<12 \mathrm{gm} / \mathrm{dl}$ & 96 & 43.6 \\
\hline Mild anemia & $11-11.9 \mathrm{gm} / \mathrm{dl}$ & 38 & 17.3 \\
\hline Moderate anemia & $8-10.9 \mathrm{gm} / \mathrm{dl}$ & 78 & 35.5 \\
\hline Severe anemia & $<8 \mathrm{gm} / \mathrm{dl}$ & 8 & 3.6 \\
\hline Total & 220 & 100 & \\
\hline
\end{tabular}

Figure1: Assessment with level prevalence of nutritional anemia

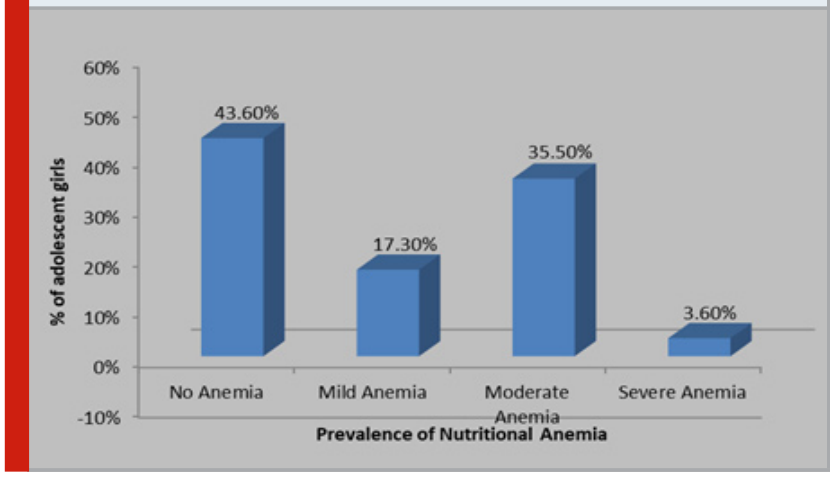

Figure 2: Assessment with perceived causes of nutritional anemia among those adolescent girls are anemic

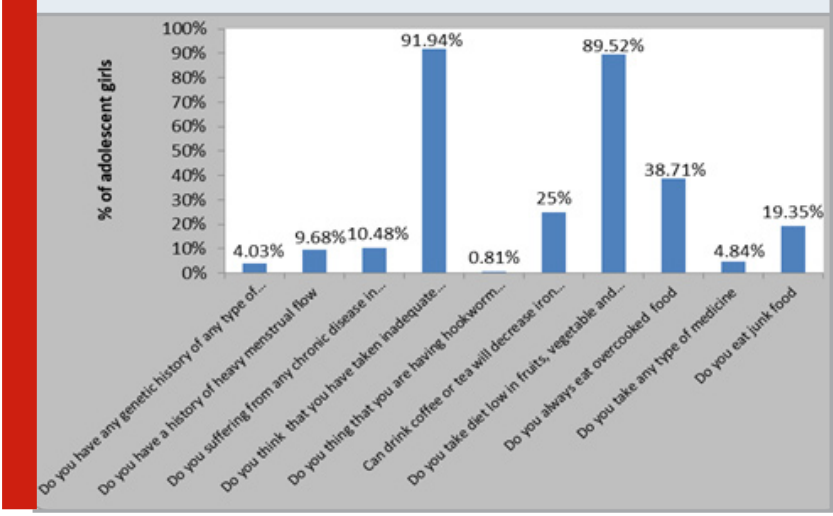

Association of perceived causes of nutritional anemia among adolescent girls: This table no.5 shows the association of perceived causes of nutritional anemia with demographic variable of adolescent girls. There is significant association of perceived causes of nutritional anemia with type of diet of adolescent girls. The tabulated ' $F$ ' values was $1.98(\mathrm{df}=122)$ which is much less than the calculated ' $F$ ' i.e. 2.14 at 5\% level of significance. Also the calculated ' $p$ ' $=0.034$ which was much less than the acceptable level of significance i.e. ' $p$ ' $=0.05$. Hence it is interpreted that type of diet of adolescent girls is statistically associated with perceived causes of nutritional anemia (Meenal et al., 2012).

The study was conducted to assess the prevalence and perceived causes of nutritional anemia among adolescent girls, the study was conducted among 220 adolescent girls in selected community area. In this study cross sectional survey design adopted. Hb estimation done by portable hemoglobinometer (Accusure HB meter) and interpretation done on WHO cut off value. Mild anemia $>11 \mathrm{gm} / \mathrm{dl}$ to $<11.9 \mathrm{gm} / \mathrm{dl}$, moderate anemia $>8 \mathrm{gm} / \mathrm{dl}$ to $<10.9 \mathrm{gm} / \mathrm{dl}$ and severe anemia $<8 \mathrm{gm} / \mathrm{dl}$. Out of 220 adolescent girls that $43.6 \%$ of adolescent girls had no anemia, $17.3 \%$ of them had mild anemia, $35.5 \%$ of them had moderate anemia and 3.6\% of them had severe anemia. Prevalence of nutritional anemia among adolescent girls was 56.4\% (Khokhar 2012 \&t Kotecha 2011).

A similar cross-sectional study was conducted in western Maharashtra among 300 female students those studying at a health institute in western Maharashtra Their general information, knowledge about anemia signs and symptoms, and dietary patterns are all elicited using a standardized questionnaire. Using the spectroscopy process, each participant's basal metabolic index and hemoglobin are calculated. The result showing anemia rate of 86 percent ( 28.6 percent), according to the severity of anemia, approximately 54 (18\%) had mild anemia and $32(10.6 \%)$ had severe anemia (Mayura et al., 2014).

Another similar study done to assess the prevalence of anemia in girls who live in urban slum at Jaitala, Nagpur from 2009 June to 2010 February. The participants are the 272 adolescent girl's age between 10 to 19 years. The prevalence of anemia is found $90.1 \%$ in girls. 88.6 per cent of the majority of girls had mild to moderate anemia and just 1.5 per cent of girls were seriously anemic. Overall mean hemoglobin level was $10.33 \pm 1.34$.10 Prevalence of anemia associate with education of caretaker. This present study show the association between the prevalence of nutritional anemia of adolescent girls with education of caretaker 
were significant i.e. $p=0.0001$. Hence it is interpreted that there was significant association with education of caretaker which explains its higher prevalence in high educated family (Melwani et al., 2018).

\begin{tabular}{|c|c|c|c|c|c|c|c|c|c|}
\hline $\begin{array}{c}\text { Demogr } \\
\text { aphic } \\
\text { variable } \\
\text { s } \\
\end{array}$ & $\begin{array}{c}\text { Frequ } \\
\text { ency }\end{array}$ & 之举 & 흘 콜 & 홀 & 总咅 & 总 & $=$ & 层: & 总 \\
\hline & & & & ge $(y)$ & rs) & & & & \\
\hline 10 yrs & 34 & 12 & 9 & \begin{tabular}{l|}
1 \\
2
\end{tabular} & 1 & \multirow{6}{*}{$\begin{array}{l}12 \\
.7 \\
3\end{array}$} & \multirow{6}{*}{$\begin{array}{l}1 \\
5\end{array}$} & \multirow{6}{*}{$\begin{array}{l}24 \\
.9 \\
9\end{array}$} & \multirow{6}{*}{$\begin{array}{c}0.62, \\
N S, p>0.05\end{array}$} \\
\hline $11 \mathrm{yrs}$ & 28 & 14 & 5 & 8 & 1 & & & & \\
\hline $12 \mathrm{yrs}$ & 35 & 14 & 4 & $\begin{array}{l}1 \\
6\end{array}$ & 1 & & & & \\
\hline 13 yrs & 28 & 13 & 4 & 9 & 2 & & & & \\
\hline $14 \mathrm{yrs}$ & 43 & 24 & 3 & $\begin{array}{l}1 \\
5\end{array}$ & 1 & & & & \\
\hline $15 \mathrm{yrs}$ & 52 & 19 & \begin{tabular}{l|}
1 \\
3
\end{tabular} & \begin{tabular}{l|}
1 \\
8
\end{tabular} & 2 & & & & \\
\hline \multicolumn{10}{|c|}{ Education of adolescent girls } \\
\hline $4-5^{\text {th }}$ std & 62 & 26 & \begin{tabular}{l|l}
1 \\
4
\end{tabular} & \begin{tabular}{l|}
2 \\
0 \\
\end{tabular} & 2 & \multirow{4}{*}{$\begin{array}{l}7 . \\
55\end{array}$} & \multirow{4}{*}{9} & \multirow{4}{*}{$\begin{array}{l}16 \\
.9 \\
2\end{array}$} & \multirow{4}{*}{$\begin{array}{c}0.58, \\
\text { NS, p }>0.05\end{array}$} \\
\hline $6-7^{\text {th }}$ std & 61 & 27 & 8 & $\begin{array}{l}2 \\
3 \\
\end{array}$ & 3 & & & & \\
\hline $8-9^{\text {th }}$ std & 91 & 41 & $\begin{array}{l}1 \\
3 \\
\end{array}$ & $\begin{array}{l}3 \\
4 \\
\end{array}$ & 3 & & & & \\
\hline $10^{\text {th }}$ std & 6 & 2 & 3 & 1 & o & & & & \\
\hline \multicolumn{10}{|c|}{ Education of caretakers } \\
\hline Illiterate & 1 & 0 & \begin{tabular}{l|l}
0 \\
\end{tabular} & 1 & 0 & \multirow{7}{*}{$\begin{array}{l}72 \\
.7 \\
3\end{array}$} & \multirow{7}{*}{$\begin{array}{l}1 \\
8\end{array}$} & \multirow{7}{*}{$\begin{array}{l}28 \\
.8 \\
7\end{array}$} & \multirow{7}{*}{$\begin{array}{c}0.0001, \\
\mathrm{~s}, \mathrm{p}>0.05\end{array}$} \\
\hline Primary & 22 & 6 & 1 & $\begin{array}{l}1 \\
2\end{array}$ & 3 & & & & \\
\hline $\begin{array}{c}\text { Seconda } \\
\text { ry }\end{array}$ & 27 & 2 & 6 & $\begin{array}{l}1 \\
7 \\
\end{array}$ & 2 & & & & \\
\hline $\mathrm{SSC}$ & 51 & 12 & $\begin{array}{l}1 \\
5\end{array}$ & $\begin{array}{l}2 \\
1 \\
\end{array}$ & 3 & & & & \\
\hline HSC & 54 & 26 & $\begin{array}{l}1 \\
2\end{array}$ & $\begin{array}{l}1 \\
6 \\
\end{array}$ & o & & & & \\
\hline $\begin{array}{l}\text { Undergr } \\
\text { aduate }\end{array}$ & 42 & 32 & 2 & 8 & o & & & & \\
\hline $\begin{array}{l}\text { Graduat } \\
\text { e and } \\
\text { above }\end{array}$ & 23 & 18 & 2 & 3 & o & & & & \\
\hline \multicolumn{10}{|c|}{ Monthly Income (Rs) } \\
\hline $\begin{array}{c}\text { Rs. } \\
5001- \\
10000\end{array}$ & 115 & 48 & $\begin{array}{l}1 \\
8\end{array}$ & $\begin{array}{l}4 \\
2\end{array}$ & 7 & \multirow{3}{*}{$\begin{array}{l}11 \\
.2 \\
7\end{array}$} & \multirow{4}{*}{9} & \multirow{3}{*}{$\begin{array}{l}16 \\
.9 \\
2\end{array}$} & \multirow{3}{*}{$\begin{array}{c}0.25, \\
\mathrm{NS}, \mathrm{p}>0.05\end{array}$} \\
\hline $\begin{array}{c}\text { Rs. } \\
10001- \\
15000\end{array}$ & 82 & 33 & $\begin{array}{l}1 \\
5\end{array}$ & $\begin{array}{l}3 \\
3\end{array}$ & 1 & & & & \\
\hline $\begin{array}{c}\text { Rs. } \\
15001- \\
20000\end{array}$ & 18 & 12 & 4 & 2 & o & & & & \\
\hline $\begin{array}{l}\mathrm{R} 20001 \\
\text { and } \\
\text { above }\end{array}$ & 5 & 3 & 1 & 1 & o & & & & \\
\hline \multicolumn{10}{|c|}{ Type of family } \\
\hline Joint & 110 & 41 & \begin{tabular}{l|}
2 \\
1
\end{tabular} & \begin{tabular}{l|}
4 \\
4 \\
\end{tabular} & 4 & \multirow{3}{*}{$\begin{array}{l}8 . \\
85\end{array}$} & \multirow{3}{*}{6} & \multirow{3}{*}{$\begin{array}{l}12 \\
.5 \\
9\end{array}$} & \multirow{3}{*}{$\begin{array}{c}0.18, \\
\text { NS, p }>0.05\end{array}$} \\
\hline Nuclear & 102 & 48 & $\begin{array}{l}1 \\
7 \\
\end{array}$ & $\begin{array}{l}3 \\
3 \\
\end{array}$ & 4 & & & & \\
\hline $\begin{array}{c}\text { Extende } \\
d\end{array}$ & 8 & 7 & 0 & 1 & o & & & & \\
\hline \multicolumn{10}{|c|}{ Type of diet } \\
\hline $\begin{array}{c}\text { Vegetari } \\
\text { an }\end{array}$ & 77 & 28 & \begin{tabular}{l|l}
1 \\
0
\end{tabular} & \begin{tabular}{l|}
3 \\
4 \\
\end{tabular} & 5 & \multirow{3}{*}{$\begin{array}{l}8 . \\
27\end{array}$} & \multirow{3}{*}{4} & & \\
\hline $\begin{array}{c}\text { Non } \\
\text { Vegetari } \\
\text { an } \\
\end{array}$ & 0 & 0 & o & $\mathrm{o}$ & o & & & $\begin{array}{l}9 . \\
48\end{array}$ & $\begin{array}{c}0.082, \\
N S, p>0.05\end{array}$ \\
\hline Mixed & 143 & 68 & $\begin{array}{l}2 \\
8 \\
\end{array}$ & $\begin{array}{l}4 \\
4 \\
\end{array}$ & 3 & & & & \\
\hline
\end{tabular}

A similar study was conducted in the year of 2003. This cross sectional study was conducted in Nagpur among adolescent females in the urban area. A total 296 adolescent females, age of 10-19 year were participated in the research. In result prevalence of anemia found
35.1\% and a found a significant association of anemia with the literacy of parents.11 Association of perceived causes of nutritional anemia among adolescent girls in relation to type of diet Present study show the association between the perceived causes of nutritional anemia 
of adolescent girls with type of diet were significant i.e. $p=0.034$. Hence it is interpreted that there was significant association with type of diet which explains the adolescent girls having a good knowledge those are taking mix diet (Milman 2011).

Table $3 \mathrm{n}=124$

\begin{tabular}{|c|c|c|c|c|c|c|}
\hline $\begin{array}{c}\text { Demographic } \\
\text { variables }\end{array}$ & $\begin{array}{c}\text { No. of } \\
\text { adolescent } \\
\text { girls }\end{array}$ & $\begin{array}{c}\text { Mean Score } \pm \\
\text { SD }\end{array}$ & F-value & df & $\begin{array}{l}\text { F-tab } \\
\text { value }\end{array}$ & p-value \\
\hline \multicolumn{7}{|c|}{ Age (yrs) } \\
\hline $10 \mathrm{yrs}$ & 22 & $3 \pm 1.02$ & \multirow{6}{*}{0.94} & \multirow{6}{*}{5,118} & \multirow{6}{*}{2.29} & \multirow{6}{*}{$\begin{array}{c}0.45, \\
\mathrm{NS}, \mathrm{p}>0.05\end{array}$} \\
\hline $11 \mathrm{yrs}$ & 14 & $2.64 \pm 0.84$ & & & & \\
\hline 12 yrs & 21 & $2.85 \pm 0.96$ & & & & \\
\hline 13 yrs & 15 & $2.66 \pm 1.04$ & & & & \\
\hline 14 yrs & 19 & $3.10 \pm 0.99$ & & & & \\
\hline 15 yrs & 33 & $3.12 \pm 0.81$ & & & & \\
\hline \multicolumn{7}{|c|}{ Education of adolescent girls } \\
\hline $4-5^{\text {th }}$ std & 36 & $2.86 \pm 0.96$ & \multirow[b]{4}{*}{0.84} & \multirow[b]{4}{*}{3,120} & \multirow[b]{4}{*}{2.68} & \multirow[b]{4}{*}{$\begin{array}{c}0.47 \\
\mathrm{NS}, \mathrm{p}>0.05\end{array}$} \\
\hline $6-7^{\text {th }}$ std & 34 & $2.79 \pm 1.00$ & & & & \\
\hline $8-9^{\text {th }}$ std & 50 & $3.10 \pm 0.88$ & & & & \\
\hline $10^{\text {th }}$ std & 4 & $3.00 \pm 0.81$ & & & & \\
\hline \multicolumn{7}{|c|}{ Education of caretaker } \\
\hline Illiterate & 1 & $3 \pm 0$ & \multirow{7}{*}{0.77} & \multirow{7}{*}{6,117} & \multirow{7}{*}{2.18} & \multirow{7}{*}{$\begin{array}{c}0.59, \\
\mathrm{NS}, \mathrm{p}>0.05\end{array}$} \\
\hline Primary & 16 & $3.06 \pm 0.77$ & & & & \\
\hline Secondary & 25 & $3.04 \pm 1.09$ & & & & \\
\hline SSC & 38 & $2.73 \pm 0.86$ & & & & \\
\hline $\mathrm{HSC}$ & 28 & $2.67 \pm 1.02$ & & & & \\
\hline Undergraduate & 11 & $3.18 \pm 0.75$ & & & & \\
\hline Graduate and above & 5 & $3 \pm 1.22$ & & & & \\
\hline \multicolumn{7}{|c|}{ Monthly income(Rs) } \\
\hline $5001-10000 \mathrm{Rs}$ & 68 & $2.95 \pm 0.95$ & \multirow{4}{*}{1.92} & \multirow{4}{*}{3,120} & \multirow[b]{4}{*}{2.68} & \multirow[b]{4}{*}{$\begin{array}{c}0.13 \\
\text { NS, } p>0.05\end{array}$} \\
\hline $10001-15000 \mathrm{Rs}$ & 47 & $2.85 \pm 0.85$ & & & & \\
\hline $15001-20000 \mathrm{Rs}$ & 7 & $2.14 \pm 1.21$ & & & & \\
\hline $\begin{array}{c}20001 \mathrm{Rs} \text { and } \\
\text { above }\end{array}$ & 2 & $3.50 \pm 0.70$ & & & & \\
\hline \multicolumn{7}{|c|}{ Type of family } \\
\hline Joint & 70 & $2.87 \pm 0.99$ & \multirow{3}{*}{0.01} & \multirow{3}{*}{2,121} & \multirow{3}{*}{3.07} & \multirow{3}{*}{$\begin{array}{c}0.98, \\
N S, p>0.05\end{array}$} \\
\hline Nuclear & 53 & $2.88 \pm 0.89$ & & & & \\
\hline Extended & 1 & $3 \pm 0$ & & & & \\
\hline \multicolumn{7}{|c|}{ Type of diet } \\
\hline Vegetarian & 48 & $3.10 \pm 0.88$ & \multirow{3}{*}{2.14} & \multirow{3}{*}{122} & \multirow{3}{*}{1.98} & \\
\hline Non Vegetarian & 0 & - & & & & 0.034 \\
\hline Mixed & 76 & $2.73 \pm 0.95$ & & & & $\mathrm{NS}, \mathrm{p}>0.05$ \\
\hline
\end{tabular}

A cross sectional study was conducted to find prevalence of anemia and various factors influencing anemia among adolescent girls in urban and rural field practice areas of Osmania Medical College. In present study those who were taking meat more than once a week had less percentage of anemia 38 (36.9). Those respondents who never took green leafy vegetables have more prevalence of anemia in both areas. 12

\section{CONCLUSION}

There is found a significant association between prevalence of nutritional anemia among adolescent girls with education of caretaker and perceived causes of nutritional anemia among adolescent girls with the type of diet. 


\section{REFERENCES}

Cappellini MD, Motta I. (2015). Anemia in Clinical Practice-Definition and Classification: Does Hemoglobin Change With Aging? SeminHematol. Oct;52(4):261-9. Chaudhary SM, Dhage VR. (2008 0ct). A study of anemia among adolescent females in the urban area of Nagpur. Indian journal of community medicine: official publication of Indian Association of Preventive \& Social Medicine ; 33(4):243.

De Benoist B, Cogswell M, Egli I, McLean E. Worldwide prevalence of anaemia 1993-2005; WHO Global Database of anaemia.

Dr. MeenalVinay Kulkarni, P M Durge, N B Kasturwar (2012). Prevalence of anemia among adolescent girls in an urban slum at Nagpur,National Journal of community medicine Vol3issue 1jan-march.

Khokhar K. (2012). Anaemia 'a silent killer' among Women in India: Present Scenario.

Kotecha PV. (2011). Nutritional Anemia in Young Children with Focus on Asia and India. Indian J Community Med ;36(1):8-16.

Mayura S, Suguna E, Dongre AR. (2014). Perceived Cause and Effect Relationship for Nutritional AnemiaAmong Adolescent Girls in Rural Puducherry. Online J Health
Allied Scs ;13(3):2.

Melwani V, Dubey M, Khan A, Toppo M, Choudhary Y, Priya A. (2018). A study to assess the prevalence of anaemia amongst adolescent girls residing in selected slum of Bhopal city. International Journal of Community Medicine And Public Health. 24;5:1096.

Milman N. (2011) Anemia-still a major health problem in many parts of the world!. Annals of hematology.;90(4):369-77.

Rani GS, Baburao B. (2017). A study on prevalence of anaemia and various factors influencing anaemia among adolescent girls in urban and rural field practice areas of Osmania Medical College. International Journal Of Community Medicine And Public Health. 23;4(9):3319-23.

Vibhute NA, Shah U, Belgaumi U, Kadashetti V, Bommanavar S, Kamate W. (2019). Prevalence and awareness of nutritional anemia among female medical students in Karad, Maharashtra, India: A cross-sectional study. Journal of family medicine and primary care ;8(7):2369.

World Health Organization. Nutritional anaemias: report of a WHO scientific group [meeting held in Geneva from 13 to 17 March 1967]. World Health Organization; 1968. 